\title{
Marandu palisadegrass growth under nitrogen and sulphur for replacing Signal grass in degraded tropical pasture
}

\author{
Fabiano Daniel De Bona ${ }^{1}$; Francisco Antonio Monteiro ${ }^{2 *}$ \\ ${ }^{1}$ USP/ESALQ - Programa de Pós-Graduação em Solos e Nutrição de Plantas. \\ ${ }^{2}$ USP/ESALQ - Depto. de Ciência do Solo, C.P. 09 - 13418-900 - Piracicaba, SP - Brasil. \\ *Corresponding author <famontei@esalq.usp.br>
}

\begin{abstract}
The degradation of Brachiaria decumbens Stapf. (Signal grass) pastures has resulted in a big problem for the Brazilian cattlemen. The objective of this study was to assess fertilization with nitrogen $(\mathrm{N})$ and sulphur (S) rates on yield of Brachiaria brizantha (Hochst. ex A. Rich.) Stapf. cv. Marandu (Marandu palisadegrass) under establishment in a soil supporting degrading pasture of Brachiaria decumbens Stapf. Additionally, the $\mathrm{N}$ and $\mathrm{S}$ concentrations in plant tissue and soil according to the rates of these nutrients were evaluated. The study was carried out in a greenhouse in pots filled with an Entisol with high organic matter content. Five rates of $\mathrm{N}\left(0 ; 100 ; 200 ; 300\right.$ and $\left.400 \mathrm{mg} \mathrm{dm}^{-3}\right)$ and five rates of $\mathrm{S}\left(0 ; 10 ; 20 ; 30\right.$ and $\left.40 \mathrm{mg} \mathrm{dm}^{-3}\right)$ were tested in a $5^{2}$ fractionated factorial. Plants were harvest three times. The interaction $\mathrm{N}$ rates $\times \mathrm{S}$ rates was significant for the variables leaf area, tiller number, shoot dry matter, $\mathrm{N}$ concentration and N:S ratio in plants, and total $\mathrm{N}$ and sulphur-sulphate in the soil in at least one of the three growth periods of Marandu palisadegrass in establishment. The supply of both $\mathrm{S}$ and $\mathrm{N}$ to reach the $\mathrm{N}: \mathrm{S}$ ratio about 10:1 in the fertilization promoted high yield, adequate $\mathrm{N}$ and $\mathrm{S}$ concentrations for plant metabolism and forage production, as well as kept and/ or raised the soil fertility in relation to these nutrients.
\end{abstract}

Key words: Brachiaria brizantha (Hochst. ex A. Rich.) Stapf., fertilizer, production, N:S ratio

\section{Substituição do capim-Braquiária pelo capim-Marandu em pastagens tropicais degradadas com o uso combinado de nitrogênio e de enxofre}

\begin{abstract}
RESUMO: A degradação de pastagens formadas por plantas de Brachiaria decumbens Stapf. (capim-Braquiária) é um problema que assola os pecuaristas brasileiros. Avaliaram-se combinações de doses de nitrogênio (N) e de enxofre (S) na produção da Brachiaria brizantha (Hochst. ex A. Rich.) Stapf. cv. Marandu (capim-Marandu) em implantação em solo de área vegetada com capim-Braquiária em degradação, e as alterações nas concentrações desses elementos no tecido vegetal e no solo promovidas pela adubação com N e S. O experimento foi realizado em casa de vegetação em vasos contendo Neossolo Quartzarênico com expressivo teor de matéria orgânica. Avaliaram-se cinco doses de N (0;100; 200; 300 e $\left.400 \mathrm{mg} \mathrm{dm}^{-3}\right)$ combinadas com cinco doses de S $(0 ; 10 ; 20 ; 30$ e $40 \mathrm{mg} \mathrm{dm}^{-3}$ ), em um fatorial $5^{2}$ fracionado. Realizaram-se três cortes das plantas de capim-Marandu. A interação doses de $\mathrm{N} \times$ doses de $\mathrm{S}$ na adubação foi significativa para as variáveis área foliar total, número de perfilhos, massa seca da parte aérea, concentração de $\mathrm{N}$ e relação $\mathrm{N}: \mathrm{S}$ na planta, e teores de $\mathrm{N}$ total e enxofresulfato do solo em pelo menos um dos três crescimentos do capim-Marandu. A relação N:S no fertilizante em aproximadamente 10:1 propiciou elevada produção de massa seca, com concentrações de $\mathrm{N}$ e de $\mathrm{S}$ adequadas para o metabolismo da planta e produção de forragem, bem como manteve e/ou incrementou a fertilidade do solo em relação aos referidos nutrientes.

Palavras-chave: Brachiaria brizantha (Hochst. ex A. Rich.) Stapf., fertilizante, produção, relação N:S
\end{abstract}

\section{Introduction}

Animals exclusively fed with grasses from natural or cultivated pastures characterize a large part of the Brazilian beef cattle production. Brazil has around 172 million hectares of grasslands that support a cattle herd of approximately 170 million heads (IBGE, 2006). About $55 \%$ of the total area of pastures is composed by grasses of the genus Brachiaria (Ferraz, 2003), due to its high adaptability to variable conditions of climate and soil (Keller-Grein et al., 1996), and an availability of seed for trade. In recent decades, pastures of Brachiaria decumbens Stapf. (Signal grass) are present- ing serious problems of degradation in several regions of the country.

Trying to solve the problem of Brachiaria decumbens pasture degradation, many farmers have decided for using Brachiaria brizantha cultivars to establish the new pasture. These grasses chosen for this replacement, however, usually need more amounts of nutrients and without adequate plant nutrition the objective cannot be fully achieved.

Considering the nutritional status, grasses response to nitrogen (N) fertilization is positive (Lauriault et al., 2002; Reich et al., 2003; Xia and Wan, 2008). Although $\mathrm{N}$ availability is important for the production of pas- 
tures established with Brachiaria (Boddey et al., 2004), $\mathrm{N}$ has not usually been the unique limiting nutrient in areas of degraded pastures (Oliveira et al., 2004). Elements like sulphur (S), which is connected directly to $\mathrm{N}$ in the process of synthesis of proteins (Crawford et al., 2000) could be under inadequate concentration for plant optimal development and growth in these soils. Thus, possibly $\mathrm{N}$ and $\mathrm{S}$ supply together is needed for enhancing the grass production.

The objective of the present study was to evaluate combinations of $\mathrm{N}$ and $\mathrm{S}$ rates in the production of tropical grass Brachiaria brizantha (Hochst. ex A. Rich.) Stapf. cv. Marandu (Marandu palisadegrass), recently established in a previously degraded pasture covered with Signal grass and to assess changes in the concentrations of these elements in plant tissue and soil promoted by fertilization with $\mathrm{N}$ and $\mathrm{S}$.

\section{Material and Methods}

The study was performed with soil from pasture area cultivated with Brachiaria decumbens Stapf. during 12 years, located in the city of Santa Maria da Serra (2234' S, 4809' W), São Paulo State, Brazil. The soil is an Entisol. Since the pasture establishment, the area was not limed or fertilized, showing currently uncovered areas with small and chlorotic plants characterizing the first stage of degradation. The research was carried out under controlled conditions (glass greenhouse and controlled air temperature and irrigation), because the goal was to test a greater number of combinations of $\mathrm{N}$ and $S$ rates, and isolate the effects of fertilization treatments from possible environmental interferences such as temperature, water supply and also deposition of animal excreta.

The experiment was carried out in plastic pots with $3.6 \mathrm{~L}$ capacity (internal height $=20.0 \mathrm{~cm}$ and internal diameter $=18.0 \mathrm{~cm}$ ) in greenhouse at Piracicaba-SP (2243' S, 4738' W), Brazil, from January to May 2006, using the forage grass Brachiaria brizantha (Hochst. ex A. Rich.) Stapf. cv. Marandu. The average air temperature inside the greenhouse was around $30^{\circ} \mathrm{C}$. Soil samples collected in the depth $0-20 \mathrm{~cm}$ were air-dried during approximately 15 days and sieved with a $4 \mathrm{~mm}$ screen for disposal of gravels and coarse organic fractions. Each experimental unit had $5.6 \mathrm{~kg}$ of air-dried sieved soil, which had a soil density of $1.56 \mathrm{~kg} \mathrm{dm}^{-3}$.

Before implementation of the treatments the soil chemical characteristics were: $\mathrm{pH}\left(0.01 \mathrm{M} \mathrm{CaCl}_{2}\right)=4.53$; organic matter (O.M.) $=32.1 \mathrm{~g} \mathrm{~kg}^{-1}$; P-resin $=5.8 \mathrm{mg}$ $\mathrm{dm}^{-3} ; \mathrm{S}$-sulphate $=7.4 \mathrm{mg} \mathrm{dm}{ }^{-3} ; \mathrm{K}, \mathrm{Ca}, \mathrm{Mg}, \mathrm{H}+\mathrm{Al}$, base sum $(\mathrm{BS})$ and cation exchange capacity $(\mathrm{CEC})=2.43$; 13.0; 8.67; 40.0; 24.1 and $64.1 \mathrm{mmol} \mathrm{dm}^{-3}$, respectively; V (percentage base saturation) $=37.6 \%$ and $\mathrm{m}$ (aluminum saturation) $=16.9 \%$. Taking into consideration the nutritional requirements of Marandu palisadegrass, liming was performed with the objective of increasing soil base saturation to $50 \%$ by the application of $300 \mathrm{mg} \mathrm{dm}^{-3}$ of
$\mathrm{CaCO}_{3}$ and $230 \mathrm{mg} \mathrm{dm}^{-3}$ of $\mathrm{MgCO}_{3}$. After mixing the carbonates to the soil, $950 \mathrm{~mL}$ of water was added to each pot for incubation during 30 days.

Combinations of five $\mathrm{N}$ rates $(0 ; 100 ; 200 ; 300$ and $\left.400 \mathrm{mg} \mathrm{dm}^{-3}\right)$ with five $S$ rates $(0 ; 10 ; 20 ; 30$ and $40 \mathrm{mg}$ $\mathrm{dm}^{-3}$ ) were studied in a surface response of the central composed experimental design modified by a fractionated $5^{2}$ factorial, according to Littell and Mott (1975). Thirteen combinations of $\mathrm{N}$ and $\mathrm{S}$ rates $\left(\mathrm{mg} \mathrm{dm}^{-3}\right)$ were obtained: 0-0; 0-20; 0-40; 100-10; 100-30; 200-0; 200-20; 200 40; 300-10; 300-30; 400-0; 400-20 and 400-40. The experiment was set in randomized complete block design, with four replications. Nitrogen and $\mathrm{S}$ were provided as $\mathrm{NH}_{4} \mathrm{NO}_{3}$ and $\mathrm{CaSO}_{4} \cdot 2 \mathrm{H}_{2} \mathrm{O}$ respectively, and the amount of $\mathrm{Ca}$ in the experimental units was balanced by the use of $\mathrm{CaCl}_{2}$.

The fertilizations with macronutrients to the establishment of Marandu palisadegrass were: $\mathrm{P}=200 \mathrm{mg}$ $\mathrm{dm}^{-3} ; \mathrm{K}=150 \mathrm{mg} \mathrm{dm}{ }^{-3}$ and $\mathrm{Mg}=50 \mathrm{mg} \mathrm{dm}^{-3}$, which were supplied by the following sources: $\mathrm{CaH}_{2} \mathrm{PO}_{4}$, $\mathrm{KH}_{2} \mathrm{PO}_{4}, \mathrm{KCl}$ and $\mathrm{MgCl}_{2} .6 \mathrm{H}_{2} \mathrm{O}$. Fertilizations were repeated for every grass regrowth to supply $\mathrm{N}, \mathrm{S}$ and $\mathrm{K}$ at the same amounts applied for the initial growth. The additional supply of $\mathrm{Mg}$ was $20 \mathrm{mg} \mathrm{dm}^{-3}$ due to non-application of $\mathrm{P}$ after the first harvest, which reduced the amount of $\mathrm{Ca}$ to be balanced. Boron, $\mathrm{Cu}, \mathrm{Zn}$ and $\mathrm{Mo}$ were supplied before grass planting with the following sources and amounts: $\mathrm{H}_{3} \mathrm{BO}_{3}=1.5 \mathrm{mg} \mathrm{dm}{ }^{-3} ; \mathrm{CuCl}_{2} .2 \mathrm{H}_{2} \mathrm{O}$ $=2.5 \mathrm{mg} \mathrm{dm}^{-3} ; \mathrm{ZnCl}_{2}=2.0 \mathrm{mg} \mathrm{dm}^{-3}$ and $\mathrm{Na}_{2} \mathrm{MoO}_{4} \cdot 2 \mathrm{H}_{2} \mathrm{O}$ $=0.25 \mathrm{mg} \mathrm{dm}^{-3}$.

During the experimental period soil moisture in pots was maintained by a self-irrigating subsurface system that replaced water volume according to evapotranspiration rate of the soil-plant system. Five plants of Marandu palisadegrass were grown per pot. Three harvests were done in the plants, in the following periods: 43 days after transplanting, 35 days after the first harvest and 48 days after the second harvest. All plants were harvested when the mature leaves from the more developed plants began the senescence stage, regardless $\mathrm{N}$ and $S$ treatment.

Plants were cut up to $4 \mathrm{~cm}$ above the soil and the above-ground material was put to dry in a forced air oven at $65^{\circ} \mathrm{C}$ until constant mass. At the harvesting time, the number of tillers and leaf area of plants were also quantified. Leaf area was determined by using a leaf area machine model LI 3100 (LI-COR, NE, USA).

The assessment of nutritional status of the Marandu palisadegrass plants in relation to $\mathrm{N}$ and $\mathrm{S}$ nutrients was carried out in the diagnostic leaves, which are the two newly expanded leaves (Batista and Monteiro, 2007). Concentrations of total $\mathrm{N}$ and $\mathrm{S}$ were determined according to methodology described by Nelson and Sommers (1973) and Tabatabai (1982), respectively.

Soil was sampled in all pots just after every plant harvest. Soil sampling was performed with a soil probe (length $=20 \mathrm{~cm}$, diameter $=1.5 \mathrm{~cm}$ ), collecting samples 
from top to bottom of the soil body disposed in the pots. The soil samples for determination of total $\mathrm{N}$ and sulphur-sulphate were previously air-dried, ground in a mill and sieved at $2 \mathrm{~mm}$ sieve. Total soil $\mathrm{N}$ was determined by Kjeldahl method (Bremner, 1996). Sulphur-sulphate was extracted by solution of calcium phosphate and determined by turbidimetric method (Tabatabai, 1982).

The variables were treated through analysis of response surface using the Statistical Analysis System (SAS, 2004) software. Firstly the data were evaluated by ANOVA for the combinations of $\mathrm{N}$ and $\mathrm{S}$ rates in the fertilization. In cases of significant $\mathrm{N} \times \mathrm{S}$ interaction, polynomial regression analysis (response surface) through RSREG procedure was performed. In cases where the interaction $\mathrm{N} \times \mathrm{S}$ was not significant, a regression study of first and second levels for the $\mathrm{N}$ rates and/or S rates, through GLM procedures, was performed. The significance level of $5 \%$ was used for all statistical tests. The symbols $(*)$ and $(* *)$ in the members of regression equations show significance level $(p<0.05)$ and $(p<0.01)$, respectively, of the corresponding coefficients.

\section{Results and Discussion}

A positive effect of the $\mathrm{N}$ fertilization in increasing leaf area determined at the first harvest (first growth) of the plants (Figure 1a) was found. However, taking into account the leaf area at the second and third harvest (second and third growths, respectively), the interaction $\mathrm{N}$ rates $\times \mathrm{S}$ rates was significant to the total leaf area of this forage grass (Figures $1 \mathrm{~b}$ and $1 \mathrm{c}$ ). The maximum leaf area at the second harvest of grass was achieved with rates of $\mathrm{N}$ and $\mathrm{S}$ around 334 and $31 \mathrm{mg} \mathrm{dm}^{-3}$, respectively. At the third harvest, maximum leaf area of Marandu palisadegrass plants was obtained with the supply of $\mathrm{N}$ of $375 \mathrm{mg} \mathrm{dm}^{-3}$, as the amount of $\mathrm{S}$ for maximal grass leaf growth was beyond the limits tested.

During the grass establishment, the competition between growing plants was not so strong in terms of soil nutrients and space in pot. Thus, it is believed that the available $S$ in the original soil was enough to satisfy the forage plant requirements during the first growth. After the first and second harvests, the grass growth was intensified and, consequently, $\mathrm{S}$ together with $\mathrm{N}$ became very important for leaf area production. The increase in leaf area of the forage plant with supply of $\mathrm{N}$ and $\mathrm{S}$ increases the photosynthetic efficiency of the plant (Parsons et al., 1983), by enhancing the area of light interception (Akmal and Janssens, 2004).

The number of tillers was altered by the application of $\mathrm{N}$ for the first and second growths of the grasses. Data were adjusted using polynomial models of first and second levels, respectively (Figures $1 \mathrm{~d}$ and 1e). The combination of $\mathrm{N}$ and $\mathrm{S}$ rates in the composition of fertilizer affected the number of tillers of Marandu palisadegrass during the third growth period, when maximum tillering was achieved with application of 270 and $29 \mathrm{mg}$ $\mathrm{dm}^{-3}$ of $\mathrm{N}$ and $\mathrm{S}$ rates, respectively (Figure 1f).
Positive results on the effect of $\mathrm{N}$ fertilization in the tillering of forage grasses have been extensively reported by other authors (McKenzie et al., 2002; Premazzi et al., 2003). Working with Cynodon spp. in a greenhouse experiment, Premazzi et al. (2003) observed that the addition of $\mathrm{N}$ at $80 \mathrm{mg} \mathrm{dm}^{-3}$ resulted in a $65 \%$ increase in number of grass tillers. Evaluating rates of $\mathrm{N}$ ranging from 0 to $225 \mathrm{~kg} \mathrm{ha}^{-1} \mathrm{yr}^{-1}$ during three years of experiment, McKenzie et al. (2002) observed increases in the density of tillers of ryegrass (Lolium perenne L.), which raised according to the increment of $\mathrm{N}$ fertilization.

Unlikely total leaf area variable, the interaction $\mathrm{N}$ rates $\times S$ rates was significant to the number of tillers of Marandu palisadegrass only in the third growth, suggesting that $\mathrm{N}$ fertilization exerts more influence on the latter parameter. Nitrogen and its various chemical forms affect the tillering of grasses more by the action in the synthesis and translocation of the cytokinin hormone than due to the nutritional aspect (Walch-Liu et al., 2000; Wang and Below, 1996). Thus, although $\mathrm{N}$ supply is highly related to grass tillering, its action on this plant productive parameter can be regulated by the $\mathrm{S}$ fertilization (Figure 1f).

Following patterns of variation of total leaf area and tillers number (Figure 1), the production of shoot dry mass of the Marandu palisadegrass was affected by $\mathrm{N}$ fertilization on the first growth period (Figure 2a). However the interaction $\mathrm{N}$ rates $\times \mathrm{S}$ rates was significant in the shoot dry production mass during the second and third growths of the forage plants (Figures $2 b$ and 2c). Nitrogen and $\mathrm{S}$ rates that promoted maximum grass productivity were 300 and $30 \mathrm{mg} \mathrm{dm}^{-3}$ respectively in the second growth; and 321 and $31 \mathrm{mg} \mathrm{dm}^{-3}$, respectively, in the third growth of Marandu palisadegrass. These values correspond to the N:S ratio in the fertilizer near to 10:1 (Figures 2b and 2c), in agreement with ratios of $\mathrm{N}$ rates and $S$ rates of fertilizer about to $10.7: 1$ and 9.3:1, which were found to be optimal for the maximum production of total leaf area and tillers, respectively (Figures $1 b$ and $1 \mathrm{f})$.

Corroborating results of Mitchell and Blue (1989) and Kalmbacher et al. (2005), the increase in $\mathrm{N}$ supply resulted in a demand for $\mathrm{S}$ by the grass until reaching maximum productivity. This pattern of variation can be explained by the increase in requirement for $\mathrm{S}$ amino acids when the synthesis of proteins is accelerated by supply of $\mathrm{N}$ to the plant (Crawford et al., 2000).

The enhance of tillering and growth of leaf area (Figure 1) probably increased the nutritional requirements of grass in the second growth, which reflected the importance of S supply to the production of dry mass of grasses (Figure 2). Considering second and third grass harvestings (Figures $2 \mathrm{~b}$ and $2 \mathrm{c}$ ), mean production of dry mass in the treatments without $\mathrm{N}$ was $11.8 \mathrm{~g}$ per pot, while the treatment with $400 \mathrm{mg} \mathrm{dm}^{-3}$ of $\mathrm{N}$ and no $\mathrm{S}$ produced only $10.8 \mathrm{~g}$ per pot. The supply of $30 \mathrm{mg} \mathrm{dm}^{-3}$ of $\mathrm{S}$ in the treatment with $300 \mathrm{mg} \mathrm{dm}{ }^{-3}$ of $\mathrm{N}$ increased the production of dry mass of Marandu palisadegrass by ap- 

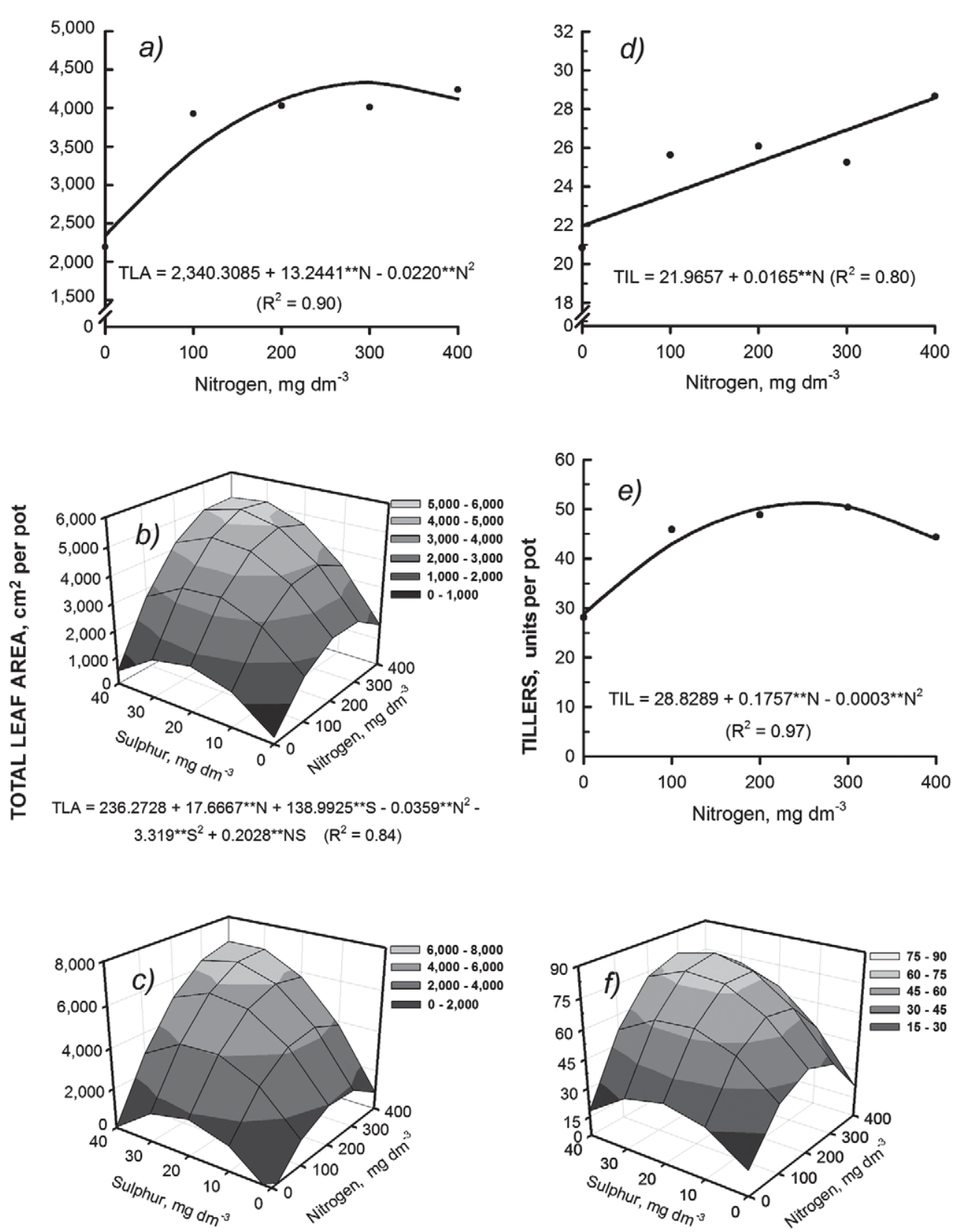

TLA $=-296.4029+19.7631^{* \star} \mathrm{N}+203.2976^{\star \star} \mathrm{S}-0.0421^{\star \star} \mathrm{N}^{2}-$ $4.8768^{\star *} S^{2}+0.3466^{\star \star} N S \quad\left(R^{2}=0.88\right)$

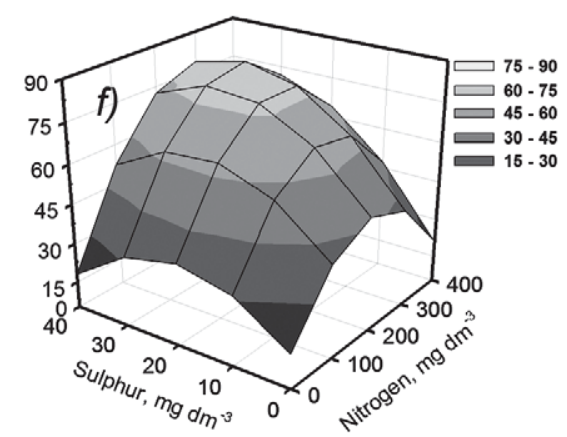

$\mathrm{TIL}=17.8489^{\star \star}+0.2910^{* \star} \mathrm{N}+1.7994^{\star *} \mathrm{~S}-0.0007^{\star *} \mathrm{~N}^{2}-$

$0.0448^{\star \star} S^{2}+0.0031^{\star \star N S} \quad\left(R^{2}=0.76\right)$

Figure 1 - Total leaf area and number of tillers related to nitrogen $(N)$ rates $(a ; d ; e)$ and combined $N$ and sulphur $(S)$ rates $(b ; c ; f)$ in the first $(\mathrm{a} ; \mathrm{d})$, second $(\mathrm{b} ; \mathrm{e})$ and third (c; f) growths of Marandu palisadegrass under establishment.

proximately $160 \%$. Similarly, Mathot et al. (2008) studied the effect of the combination of three $\mathrm{N}$ rates $(40,80$ and $\left.105 \mathrm{~kg} \mathrm{ha}^{-1}\right)$ and two $S$ rates $\left(0\right.$ and $\left.25 \mathrm{~kg} \mathrm{ha}^{-1}\right)$ in the production of Lolium spp. in eight soils from Belgium, and found that $S$ supply increased $800 \mathrm{~kg} \mathrm{ha}^{-1}$ year $^{-1}$ the dry mass production.

The interaction $\mathrm{N} \times \mathrm{S}$ was significant for concentrations of total $\mathrm{N}$ in the newly expanded leaves sampled during the first and third harvests of Marandu palisadegrass (Figures $3 \mathrm{a}$ and $3 \mathrm{c}$ ). In the second harvest, only $\mathrm{N}$ fertilization had response, which resulted in a linear increase of total $\mathrm{N}$ concentration in the diagnostic leaves (Figure 3b).

The concentration of $\mathrm{N}$ in the newly expanded leaves collected during the first harvest of Marandu palisadegrass raised with the increasing of $\mathrm{N}$ supply, as well as with the higher rates of $\mathrm{S}$ applied (Figure $3 a)$. At the third harvest of plants, the increase in the concentration of total $\mathrm{N}$ in the diagnostic leaves was more pronounced in smaller rates of $\mathrm{S}\left(0-10 \mathrm{mg} \mathrm{dm}^{-3}\right)$ 

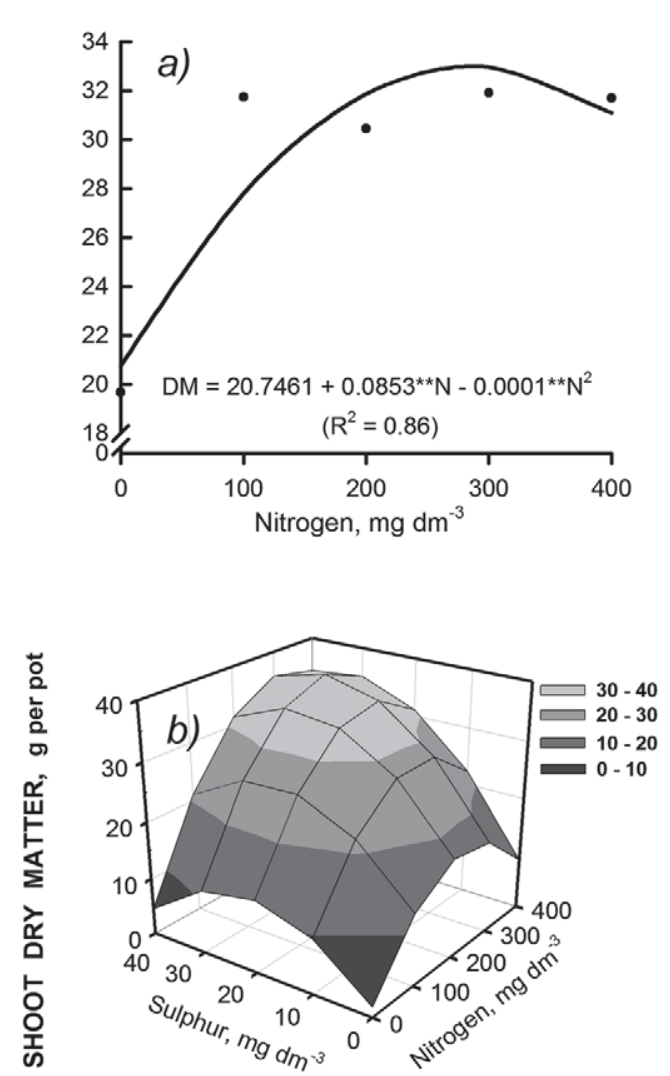

$\mathrm{DM}=1.8052+0.1380^{\star \star} \mathrm{N}+1.0262^{\star \star} \mathrm{S}-0.0003^{\star \star} \mathrm{N}^{2}-$ $0.0239^{* *} S^{2}+0.0014^{* \star} N S\left(R^{2}=0.82\right)$

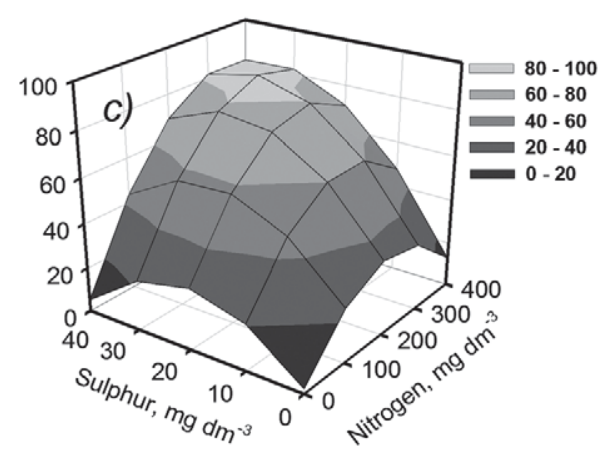

$D M=2.2370+0.2848^{\star \star} \mathrm{N}+2.4515^{\star \star} \mathrm{S}-0.0006^{\star \star} \mathrm{N}^{2}$ $0.0595^{* *} S^{2}+0.0041^{* *} N S\left(R^{2}=0.83\right)$

Figure 2 - Shoot dry matter production related to nitrogen $(\mathrm{N})$ rates (a) and combined $\mathrm{N}$ and sulphur $(\mathrm{S})$ rates (b; c) in the first (a), second (b) and third (c) growths of Marandu palisadegrass under establishment.

due to slow plant growth (Figure 3c). For the three growth periods, $\mathrm{N}$ concentration in the leaf tissue ranged from 3.2 to $39.2 \mathrm{~g} \mathrm{~kg}^{-1}$ (Figure 3). Previous works indicated mean values near to $13.0 \mathrm{~g} \mathrm{~kg}^{-1}$ as suitable values for grasses of the genus Brachiaria (CIAT, 1981; Häussler et al., 2006).

The concentration of $S$ in the newly expanded leaves did not show interaction by $\mathrm{N}$ and $\mathrm{S}$ fertilization (Figures $3 \mathrm{~d}, 3 \mathrm{e}$ and $3 \mathrm{f}$ ). For the three growth periods, the sul- phate fertilization promoted linear increases in the concentration of $S$ in the newly expanded leaves of Marandu palisadegrass, ranging from approximately 0.6 to $1.5 \mathrm{~g}$ $\mathrm{kg}^{-1}$. During the first grass growth, $\mathrm{N}$ fertilization resulted in linear increases in the $\mathrm{S}$ concentration in the leaf tissue (Figure 3d). This probably was due to the increase of root growth according to the addition of $\mathrm{N}$ to the soil (Batista and Monteiro, 2006), and also to the sulphur-sulphate readily available by mineralization of organic matter as a result of soil preparation for the experiment. In the third growth period, the increase of $\mathrm{N}$ supply resulted in changes in the concentration of $\mathrm{S}$ according to quadratic curve (Figure 3f), which reflects modifications occurred in the production of shoot dry mass due to $\mathrm{N}$ fertilization (Figure 2c), and is explained by nutrient dilution.

The N:S ratio of the newly expanded leaves sampled during the first harvest was changed by $\mathrm{N}$ fertilization. It means that $\mathrm{N}: \mathrm{S}$ ratio increased linearly from $12.4: 1$ to 19.0:1 by the supply of $\mathrm{N}$ through fertilization (Figure 4a). This result clearly demonstrates that the Marandu palisadegrass was more able to accumulate $\mathrm{N}$ than $\mathrm{S}$ in shoot tissue during the first growth period. Other authors have shown an increase in the N:S ratio in grasses with supply of $\mathrm{N}$ fertilizers (Gierus et al., 2005; Wang et al., 2002).

Evaluating the newly expanded leaves collected in the second and third harvests of Marandu palisadegrass, it was observed that N:S ratio was affected by both fertilizations with $\mathrm{N}$ and $\mathrm{S}$ rates (Figures $4 \mathrm{~b}$ and $4 \mathrm{c}$ ). It appeared that absence of $S$ in the fertilization resulted in high N:S ratio in the leaf tissue, especially when associated with high $\mathrm{N}$ fertilization $\left(400 \mathrm{mg} \mathrm{dm}^{-3}\right)$, which characterizes the metabolic imbalance of the plant (Dijkshoorn and van Wijk, 1967). According to Dijkshoorn and van Wijk (1967) the N:S ratio of 14:1 characterizes adequate nutritional status of plants from the family Poaceae (Gramineae). Assessing the data collected during the second and third harvests of Marandu palisadegrass, it was found that a ratio of 10:1 of $\mathrm{N}: \mathrm{S}$ in the fertilizer once the supply of $\mathrm{N}$ and $\mathrm{S}$ rates was more than 250 and $25 \mathrm{mg} \mathrm{dm}^{-3}$, respectively (Figures $4 \mathrm{~b}$ and $4 \mathrm{c}$ ), resulted in $\mathrm{N}: \mathrm{S}$ ratios in plant tissue that satisfied the requirements for optimal growth of the grass.

Nitrogen fertilization affected positively and linearly the total $\mathrm{N}$ concentration of the soil sampled at the end of the first and third growths of Marandu palisadegrass (Figures $5 \mathrm{a}$ and $5 \mathrm{c}$ ). The interaction $\mathrm{N}$ rates $\times \mathrm{S}$ rates was significant for this variable in the soil collected at the time of second harvest of the plants (Figure $5 \mathrm{~b}$ ). The highest rates of $\mathrm{S}\left(30-40 \mathrm{mg} \mathrm{dm}^{-3}\right)$ resulted in smaller increases in the soil $\mathrm{N}$ concentrations with the addition of $\mathrm{N}$ through fertilization. This is due to the highest extractions of this element for great production of dry mass by grasses (Figure $2 \mathrm{~b}$ ).

As $\mathrm{N}$ is a nutrient extracted from soil in large quantities by forage grasses (Boddey et al., 2004; Kalmbacher 

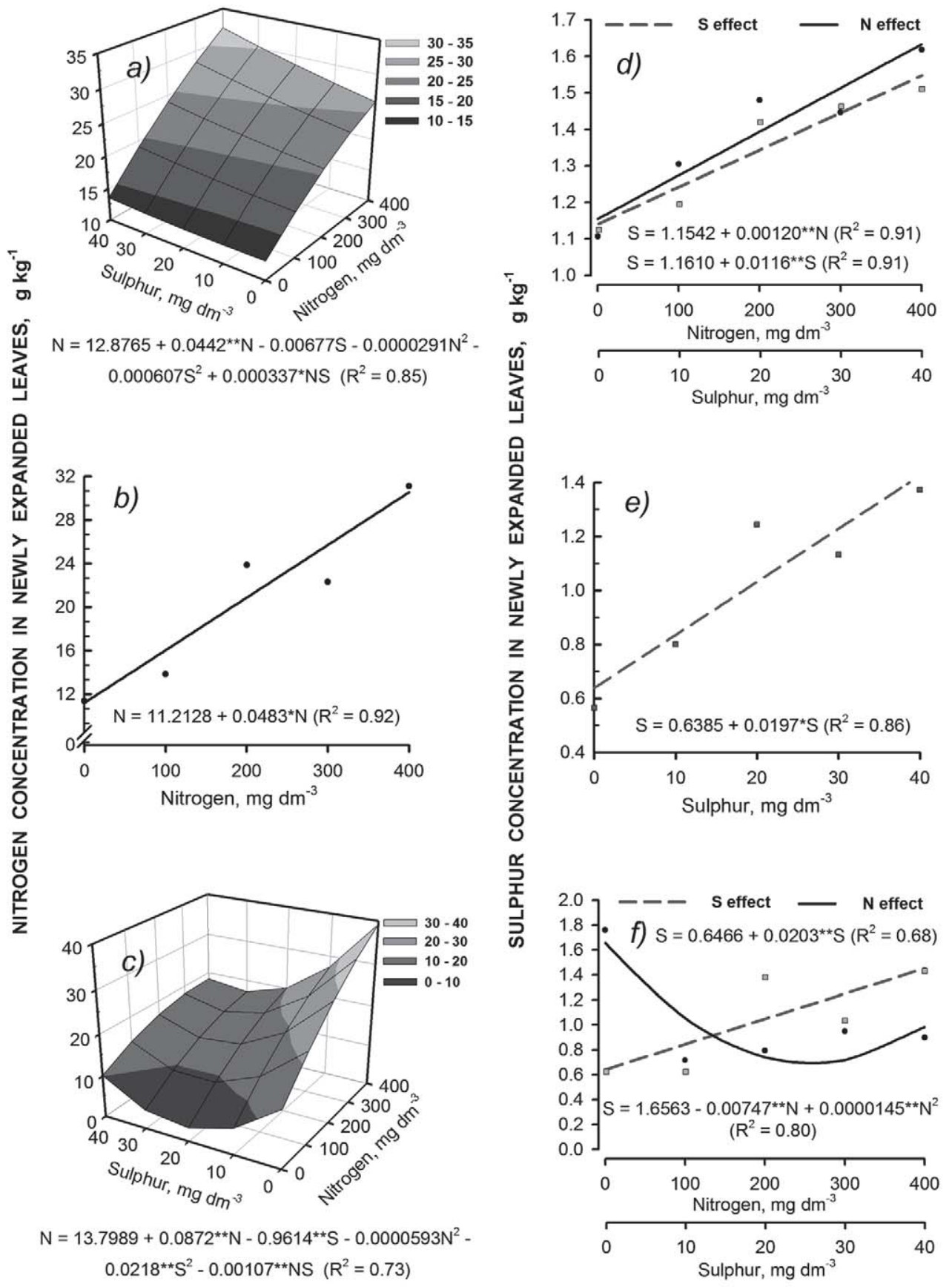

Figure 3 - Nitrogen $(N)$ and sulphur $(S)$ concentration in newly expanded leaves related to $N$ rates $(b ; d ; f), S$ rates (d; e; $f)$ and combined $\mathrm{N}$ and $\mathrm{S}$ rates $(\mathrm{a} ; \mathrm{c})$ in the first $(\mathrm{a} ; \mathrm{d})$, second $(\mathrm{b} ; \mathrm{e})$ and third $(\mathrm{c} ; \mathrm{f})$ harvests of Marandu palisadegrass under establishment.

et al., 2005; Oliveira et al., 2004), the $\mathrm{N}$ fertilization should be ideal to sustain plant production and maintain or enhance the soil $\mathrm{N}$ content. In this context, fertilization with $\mathrm{N}$ rates up to $200 \mathrm{mg} \mathrm{dm}^{-3}$ reduces about $9 \%$ the total $\mathrm{N}$ concentration in soil, from the first to the third harvest of plants, in a period of approximately 83 days (Figures 5a, 5b and 5c). On the other hand, the highest rates of $\mathrm{N}\left(300-400 \mathrm{mg} \mathrm{dm}^{-3}\right)$ kept the soil total
$\mathrm{N}$ almost unchanged, that is, the addition of $\mathrm{N}$ by fertilizers replaced the $\mathrm{N}$ removed by the grass.

The concentrations of sulphur-sulphate in the soil sampled at the time of first and second harvest of grass were changed linearly by the $\mathrm{S}$ fertilization (Figures $5 \mathrm{~d}$ and $5 \mathrm{e}$ ). The soil sulphur-sulphate concentration increased on average of six times with the supply of maximum $\mathrm{S}\left(40 \mathrm{mg} \mathrm{dm}^{-3}\right)$. During the third growth of 

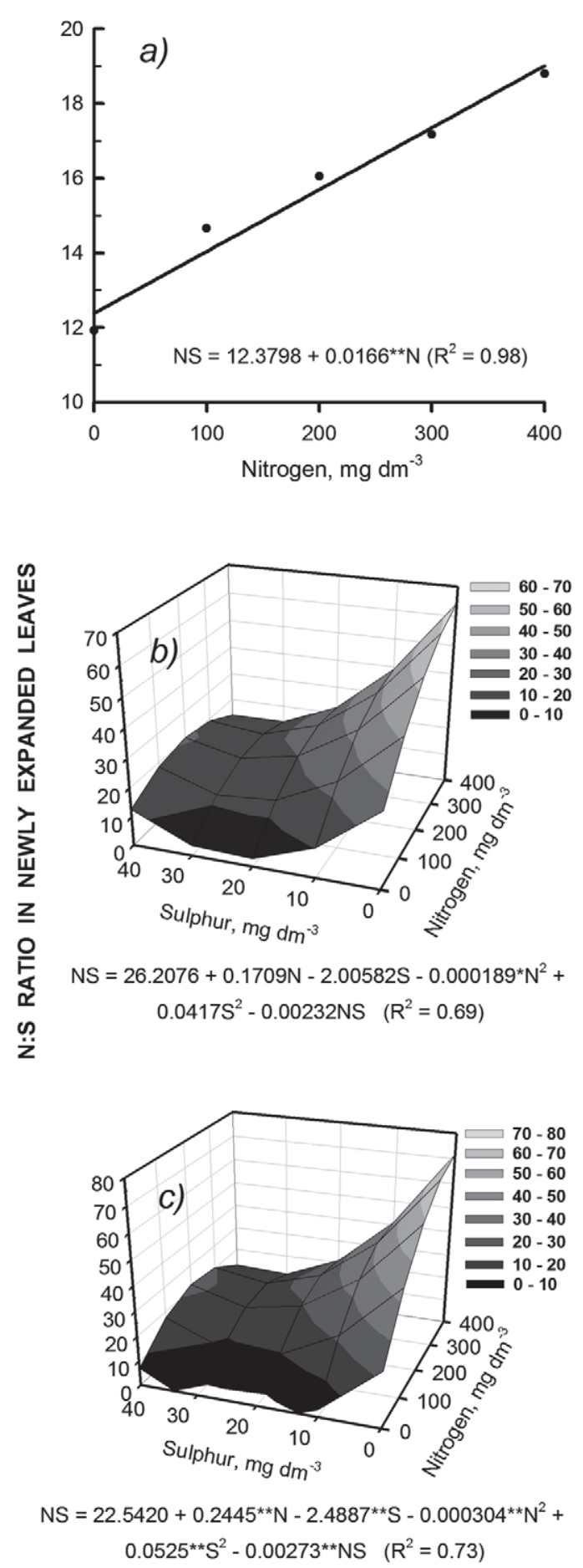

Figure 4-N:S ratio in newly expanded leaves related to nitrogen $(\mathrm{N})$ rates (a) and combined $\mathrm{N}$ and sulphur (S) rates (b; c) in the first (a), second (b) and third (c) harvests of Marandu palisadegrass under establishment.

Marandu palisadegrass the simultaneous supply of $\mathrm{N}$ and $\mathrm{S}$ affected significantly the concentration of sulphur-sulphate in the soil (Figure 5f). Increases in the proportion $\mathrm{N}$ to $\mathrm{S}$ in fertilizer reduced the sulphur-sulphate in soil by enhancing plant dry matter production (Figure 2c).
Although levels of soil sulphur-sulphate above 10 $\mathrm{mg} \mathrm{dm}^{-3}$ are considered sufficient for the establishment of pastures in Brazilian conditions (Macedo, 2004), this study showed that dry matter production of plants is maximized with $\mathrm{S}$ fertilization that raised the sulphur-sulphate concentration above this value. Thus the maximum production of shoot dry mass was obtained at $30 \mathrm{mg} \mathrm{dm}^{-3}$ of $\mathrm{S}$ rate (Figures $2 \mathrm{~b}$ and $2 \mathrm{c}$ ), which resulted in average concentration of sulphur-sulphate in the soil around $50 \mathrm{mg} \mathrm{dm}^{-3}$ (Figures $5 \mathrm{~d}, 5 \mathrm{e}$ and $5 \mathrm{f}$ ).

In average, the soil total $\mathrm{N}: \mathrm{S}$ ratio was approximately $6: 1$, which agreed with the range $3.4: 1$ to $12: 1$ observed for Brazilian agricultural soils (Neptune et al., 1975). Apparently, grass production did not occur in function of the decomposition of soil organic matter, since this variable presented mean values around $26.3,33.1$ and $33.5 \mathrm{mg} \mathrm{dm}^{-3}$, determined at the end of the first, second and third growth periods of Marandu palisadegrass, respectively.

We suggest that average $\mathrm{N}\left(300 \mathrm{mg} \mathrm{dm}^{-3}\right)$ and $\mathrm{S}$ $\left(30 \mathrm{mg} \mathrm{dm}^{-3}\right)$ rates with a ratio of 10:1 (N:S) can promote dry mass of Marandu palisadegrass in establishment to the maximum (Figures $2 \mathrm{~b}$ and $2 \mathrm{c}$ ), also met the nutritional requirements of the plant for growth and production of forage associated to the restoration of soil fertility in relation to $\mathrm{N}$ and $\mathrm{S}$ (Table 1). Although the combination of $\mathrm{N}$ and $\mathrm{S}$ rates of 300 and $30 \mathrm{mg} \mathrm{dm}^{-3}$, respectively, have resulted in a $\mathrm{N}: \mathrm{S}$ ratio in the newly expanded leaves above the adequate, it is believed that such value is within the acceptable range since the concentrations of $\mathrm{N}$ and $\mathrm{S}$ in plant tissue are in agreement with values considered to be adequate for the grass (CIAT, 1981; Häussler et al., 2006).

\section{Acknowledgements}

To The State of São Paulo Research Foundation (FAPESP) and The Brazilian National Council for Scientific and Technological Development (CNPq) for the research financial support and for providing scholarship to the authors.

\section{References}

Akmal, M.; Janssens, M.J.J. 2004. Productivity and light use efficiency of perennial ryegrass with contrasting water and nitrogen supplies. Field Crops Research 88: 143-155.

Batista, K.; Monteiro, F.A. 2006. Marandu grass root system as affected by the combinations of nitrogen and sulphur rates. Revista Brasileira de Ciência do Solo 30: 821-828 (in Portuguese, with abstract in English).

Batista, K.; Monteiro, F.A. 2007. Nitrogen and sulphur in Marandu grass: relationship between supply and concentration in leaf tissues. Scientia Agricola 64: 44-51.

Boddey, R.M.; Macedo, R.; Tarré, R.M.; Ferreira, E.; Oliveira, O.C.; Rezende, C.P.; Cantarutti, R.B.; Pereira, J.M.; Alves, B.J.R.; Urquiaga, S. 2004. Nitrogen cycling in Brachiaria pastures: the key to understanding the process of pasture decline. Agriculture, Ecosystems and Environment 103: 389403. 

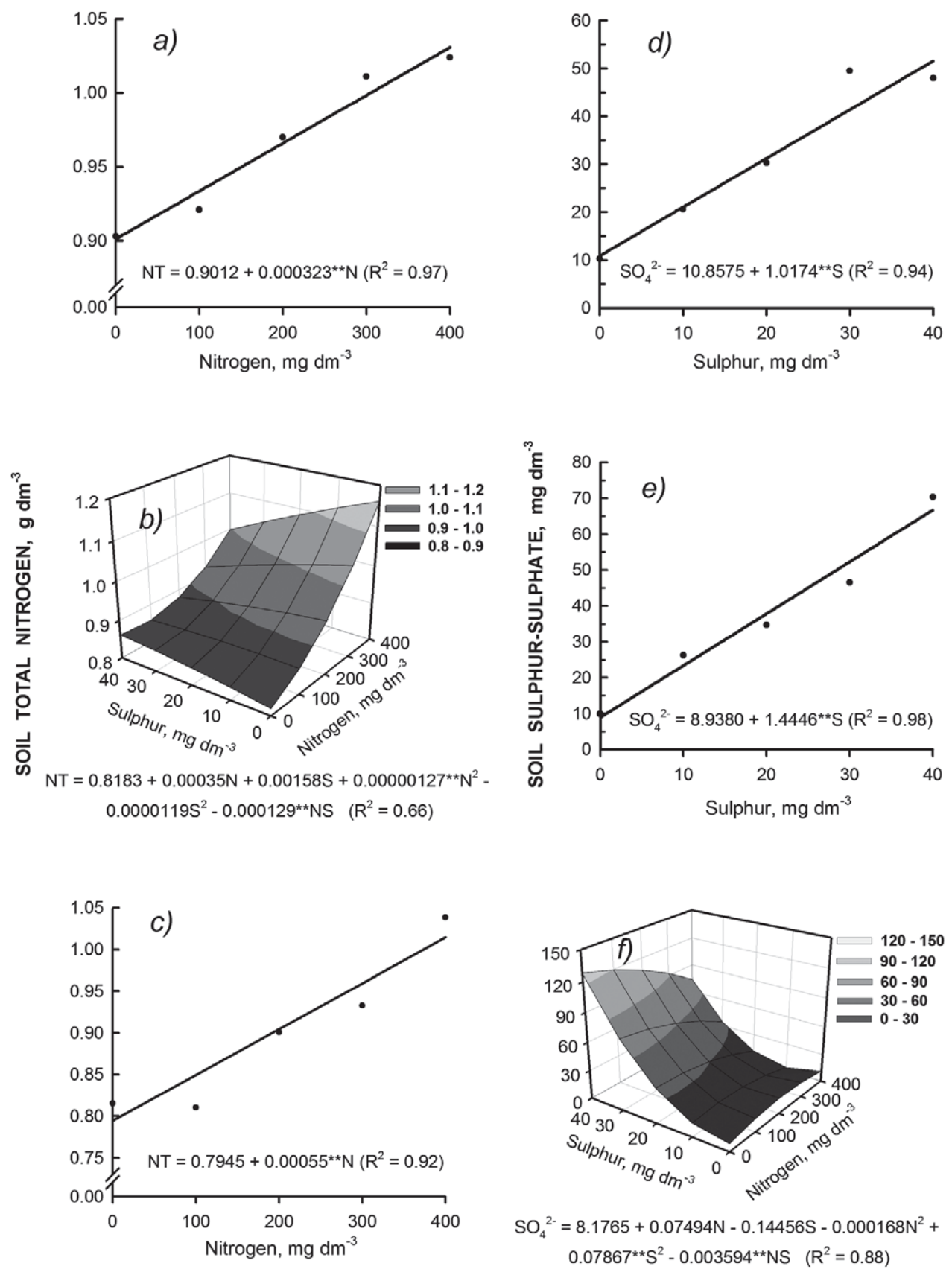

Figure 5 - Total nitrogen $(\mathrm{N})$ and sulphur-sulphate concentrations in soil related to $\mathrm{N}$ rates $(\mathrm{a} ; \mathrm{c})$, sulphur $(\mathrm{S})$ rates $(\mathrm{d} ; \mathrm{e})$ and combined $\mathrm{N}$ and $\mathrm{S}$ rates $(\mathrm{b} ; \mathrm{f})$ assessed in the first $(\mathrm{a} ; \mathrm{d})$, second $(\mathrm{b} ; \mathrm{e})$ and third $(\mathrm{c} ; \mathrm{f})$ harvests of Marandu palisadegrass under establishment.

Bremner, J.M. 1996. Nitrogen total. p. 1085-1121. In: Sparks, D.L.; Page, A.L.; Helmke, P.A.; Loeppert, R.H.; Soltanpour, P.N.; Tabatabai, M.A.; Johnston, C.T.; Summer, M.E., eds. Methods of soil analysis. Part 2: Chemical methods. SSSA-ASA, Madison, WI, USA.

International Center for Tropical Agriculture [CIAT]. 1981. Tropical Pastures Program Annual Report 1980. CIAT, Cali, Colombia.

Crawford, N.M.; Kahn, M.L.; Leustek, T.; Long, S.R. 2000. Nitrogen and sulphur. p. 786-849. In: Buchanan, B.B.; Gruissem, W.; Jones, R.L., eds. Biochemistry and Molecular Biology of Plants. American Society of Plant Physiologists, Rockville, MD, USA.
Dijkshoorn, W.; van Wijk, A.L. 1967. The sulphur requirements of plants as evidenced by the sulphur-nitrogen ratio in the organic matter: a review of published data. Plant and Soil 26: 129-157.

Ferraz, F.M. 2003. Pastures ensure the future of dairy cattle ranching. p. 55-56. In: FNP Consultoria e Comércio, ed. Anualpec 2003: anuário da pecuária brasileira. FNP, São Paulo, SP, Brazil (in Portuguese).

Gierus, M.; Jahns, U.; Wulfes, R.; Wiermann, C.; Taube, F. 2005. Forage quality and yield increments of intensive managed grassland in response to combined sulphur-nitrogen fertilization. Acta Agriculturae Scandinavica. Section B-Soil and Plant Science 55: 264-274. 
Table 1 - Nitrogen $(\mathrm{N})$ and sulphur $(\mathrm{S})$ concentration means in plant and soil, and N:S ratio in plant tissue, related to $\mathrm{N}$ and $\mathrm{S}$ rates supply of 300 and $30 \mathrm{mg} \mathrm{dm}^{-3}(\mathrm{~N}: \mathrm{S}$ ratio $=10: 1)$, respectively, which promoted approximately the maximum dry matter yield of Marandu palisadegrass during the first three growth periods of the pasture establishment.

\begin{tabular}{|c|c|c|}
\hline Variables & $\mathrm{N}: \mathrm{S}$ ratio in the fertilization $10: 1$ & Criteria $^{a}$ \\
\hline \multicolumn{3}{|l|}{ Plant } \\
\hline $\mathrm{N}$ concentration $\left(\mathrm{g} \mathrm{kg}^{-1}\right)$ & $22.81( \pm 1.42)^{\mathrm{b}}$ & Plant optimal concentration $\geq 13 \mathrm{~g} \mathrm{~kg}^{-1}$ \\
\hline $\mathrm{S}$ concentration $\left(\mathrm{g} \mathrm{kg}^{-1}\right)$ & $1.44( \pm 0.13)$ & $\begin{array}{l}\text { Plant optimal concentration not defined } \\
\text { Forage optimal concentration } \geq 1.0 \mathrm{~g} \mathrm{~kg}^{-1}\end{array}$ \\
\hline $\mathrm{N}: \mathrm{S}$ ratio & $16.8( \pm 1.20)$ & $\begin{array}{l}\text { Plant optimal N:S ratio } \approx 14 \\
\text { Forage optinal N:S ratio } \geq 10 \text { and } \leq 14\end{array}$ \\
\hline \multicolumn{3}{|l|}{ Soil } \\
\hline Total $\mathrm{N}$ concentration $\left(\mathrm{g} \mathrm{kg}^{-1}\right)$ & $0.95( \pm 0.03)$ & $\begin{array}{l}\text { High plant yield } \\
\text { Keep and/or enhance the concentration }\end{array}$ \\
\hline $\mathrm{S}_{-} \mathrm{SO}_{4}^{2-}$ concentration $\left(\mathrm{mg} \mathrm{kg}^{-1}\right)$ & $28.7( \pm 2.78)$ & Total concentration $\geq 10 \mathrm{mg} \mathrm{kg}^{-1}$ \\
\hline
\end{tabular}

Sources: Häussler et al. (2006); Perry (1980); Dijkshoorn and van Wijk (1967) and Macedo (2004). 'Standard error.

Häussler, K.; Rao, I.M.; Schultze-Kraft, R.; Marschner, H. 2006. Shoot and root growth of two tropical grasses, Brachiaria ruziziensis and $B$. dictyoneura, as influenced by aluminium toxicity and phosphorus deficiency in a sandy loam Oxisol of the eastern plains of Colombia. Tropical Grasslands 40: 213-221.

Instituto Brasileiro de Geografia e Estatística [IBGE]. 2006. Censo da Agropecuária 2006. IBGE, Rio de Janeiro, RJ, Brazil (in Portuguese).

Kalmbacher, R.S.; Ezenwa, I.V.; Arthington, J.D.; Martin, F.G. 2005. Sulfur fertilization of Bahiagrass with varying levels of nitrogen fertilization on a Florida Spodosol. Agronomy Journal 97: 661-667.

Keller-Grein, G.; Maass, B.L.; Hanson, J. 1996. Natural variation in Brachiaria and existing germplasm collections. p. 16-42. In: Miles, J.W.; Maass, B.L.; Valle, C.B.; Kumble, V., eds. Brachiaria: biology, agronomy, and improvement. CIAT, Cali, Colombia.

Lauriault, L.M.; Kirksey, R.E.; Donart, G.B. 2002. Irrigation and nitrogen effects on tall wheatgrass yield in the southern high plains. Agronomy Journal 94: 792-797.

Littell, R.C.; Mott, G.O. 1975. Computer assisted design and analysis of response surface experiments in agronomy. Soil and Crop Society of Florida Proceedings 34: 94-97.

Macedo, M.C.M. 2004. Comparative analysis of different fertilization recommendations for pastures. p. 317-355. In: Pedreira, C.G.S.; Moura, J.C.; Faria, V.P., eds. 2004. Simpósio sobre Manejo da Pastagem. FEALQ, Piracicaba, SP, Brazil (in Portuguese).

Mathot, M.; Mertens, J.; Verlinden, G.; Lambert, R. 2008. Positive effects of sulphur fertilisation on grasslands yields and quality in Belgium. European Journal of Agronomy 28: 655-658.

McKenzie, F.R.; Jacobs, J.L.; Kearney, G. 2002. The long-term impact of nitrogen fertiliser on perennial ryegrass tiller and white clover growing point densities in grazed dairy pastures in south-western Victoria. Australian Journal of Agricultural Research 53: 1203-1209.

Mitchell, C.C.; Blue, W.G. 1989. Bahiagrass response to sulfur on an Aeric Haplaquod. Agronomy Journal 81: 53-57.

Nelson, D.W.; Sommers, L.E. 1973. Determination of total nitrogen in plant material. Agronomy Journal 65: 109-112.

Neptune, A.M.L.; Tabatabai, M.A.; Hanway, J.J. 1975. Sulfur fractions and carbon-nitrogen-phosphorus-sulfur relationships in some Brazilian and Iowa soils. Soil Science Society of America Proceedings 39: 51-55.
Oliveira, O.C.; Oliveira, I.P.; Alves, B.J.R.; Urquiaga, S.; Boddey, R.M. 2004. Chemical and biological indicators of decline/ degradation of Brachiaria pastures in the Brazilian Cerrado. Agriculture, Ecosystems and Environment 103: 289-300.

Parsons, A.J.; Leafe, E.L.; Collet, B.; Stilles, W. 1983. The physiology of grass production under grazing. I. Characteristics of leaf and canopy photosynthesis of continuously-grazed swards. The Journal of Applied Ecology 20: 117-126.

Perry, T.W. 1980. Beef Cattle Feeding and Nutrition. Academic Press, London, UK.

Premazzi, L.M.; Monteiro, F.A.; Corrente, J.E. 2003. Tillering of Tifton 85 Bermudagrass in response to nitrogen rates and time of application after cutting. Scientia Agricola 60: 565-571.

Reich, P.B.; Buschena, C.; Tjoelker, M.G.; Wrage, K.; Knops, J.; Tilman, D.; Machado, J.L. 2003. Variation in growth rate and ecophysiology among 34 grasslands and savanna species under contrasting $\mathrm{N}$ supply: a test of functional group differences. New Phytologist 157: 617-631.

SAS Institute [SAS]. 2004. Statistical Analysis System for Windows: Version 9.1.2. SAS Institute, Cary, NC, USA.

Tabatabai, M.A. 1982. Sulfur. p. 501-538. In: Page, A.L.; Miller, R.H.; Keeney, D.R., eds. Methods of soil analysis. Part 2: Chemical methods. SSSA-ASA, Madison, WI, USA.

Walch-Liu, P.; Neumann, G.; Bangerth, F.; Engels, C. 2000. Rapid effects of nitrogen form on leaf morphogenesis in tobacco. Journal of Experimental Botany 51: 227-237.

Wang, S.; Wang, Y.; Schnug, E.; Haneklaus, S.; Fleckenstein, J. 2002. Effects of nitrogen and sulphur fertilization on oats yield, quality and digestibility and nitrogen and sulphur metabolism of sheep in the Inner Mongolia Steppes of China. Nutrient Cycling in Agroecosystems 62: 195-202.

Wang, X.; Below, F.E. 1996. Cytokinins in enhanced growth and tillering of wheat induced by mixed nitrogen source. Crop Science 36: 121-126.

Xia, J.; Wan, S. 2008. Global response patterns of terrestrial plant species to nitrogen addition. New Phytologist 179: 428-439.

Received April 02, 2009

Accepted April 15, 2010 